\title{
САМООРГАНІЗАЦІЯ МОЛЕКУЛ ГЕКСАДЕЦИЛБОРНОЇ КИСЛОТИ НА АТОМНО-ГЛАДКІЙ ПОВЕРХНІ ГРАФІТУ
}

\author{
A.I. CEHЕНКО,$^{1}$ O.А. МАР ЧЕНКО ${ }^{1}$ А.Г. НАУМОВЕЦЬ, ${ }^{1}$ \\ Д.Т. ТАРАЩЕНКО ${ }^{1}$ Д.А. ГЛУБОКОВ ${ }^{1,2}$ Я.З. ВОЛОШИН, ${ }^{3}$ \\ О.А. ВАРЗАЦЬКИЙ, ${ }^{4}$ О.Л. КАПІТАНЧУК ${ }^{5}$
}

${ }^{1}$ Інститут фізики НАН України

(Просп. Науки, 46, Київ 03028)

${ }^{\mathbf{2}}$ Фізичний інститут ім. П.М. Лєбєдєва РАН

(Просп. Ленінсъкий, 53, Москва 119991)

${ }^{3}$ Інститут елементоорганічних сполук ім. О.М. Несміянова РАН

(Вул. Вавилова, 28, Москва 119991)

${ }^{4}$ Інститут загальної та неорганічної хімії ім. В.І. Вернадського НАН України (Просп. Академіка Палладіна, 32/34, Київ 03142, Украӥна)

УДК 539.211, 536.9 (c) 2011

${ }^{5}$ Інститут теоретичної фізики ім. М.М. Боголюбова НАН України

(Вул. Метрологічна, 14б, Київ 03680, Украӥна)

\begin{abstract}
Показано, що високовпорядковані моношарові плівки гексадецилборної кислоти $\mathrm{CH}_{3}-\left(\mathrm{CH}_{2}\right)_{15}-\mathrm{B}(\mathrm{OH})_{2}$ можуть бути отримані на базисній площині високоорієнтованого піролітичного графіту шляхом нанесення розчину кислоти в $n$-тетрадекані $n$ - $\mathrm{C}_{14} \mathrm{H}_{30}$ при кімнатній температурі. За допомогою сканувального тунельного мікроскопа (СТМ) встановлено, що моношари мають ламелеподібну структуру, в якій кожна ламель сформована парами (димерами) молекул гексадецилборної кислоти. Асоціація молекул у димери здійснюється завдяки взаємодії між $\mathrm{B}(\mathrm{OH})_{2}$-групами. Виявлено також, що молекули розчинника $n-\mathrm{C}_{14} \mathrm{H}_{30}$, перебуваючи при температурі, значно вищій, ніж температура поверхневої кристалізації моношару тетрадекану на графіті, можуть адсорбуватись спільно з молекулами кислоти. Співадсорбцію молекул розчинника можна пояснити специфікою взаємної геометрії поверхні підкладки і димерів гексадецилборної кислоти.
\end{abstract}

\section{1. Вступ}

Надтонкі органічні плівки (ОП), нанесені на поверхню твердої підкладки, є предметом інтенсивних експериментальних і теоретичних досліджень [1-4]. Інтерес до ОП пояснюється їх широким використанням у сучасній молекулярній електроніці [5, 6], зокрема в оптоелектронних [7, 8] і запам'ятовувальних [9] пристроях, при розробці сонячних батарей [10], органічних світлодіодів і польових транзисторів [11, 12]. Крім того, впорядковані ОП є важливими модельними об'єктами, дослідження яких дозволяє поглибити уявлення про процеси самоорганізації більш складних біологічних молекул і полімерів [13]. Фізичні ха- рактеристики надтонких ОП залежать від ступеня їх упорядкованості і визначаються переважно найближчими до підкладки моношарами, тому підвищену увагу приділяють саме дослідженням структури і властивостей першого моношару.

Особливу роль у нанотехнологіях майбутнього відводять явищам самоорганізації (самозбирання) молекул на атомно-гладких поверхнях [14]. Процеси молекулярного самозбирання розглядаються як одна 3 ключових технологічних стадій при створенні двовимірних запам'ятовувальних матриць молекулярних інтегральних наносхем. Передбачається, що роль окремих елементів (діодів, транзисторів, перемикачів) у таких наносхемах будуть виконувати окремі молекули або їх невеликі ансамблі. Перехід мікроелектроніки на молекулярний рівень стає дедалі реальнішим з появою методу сканувальної тунельної мікроскопії (CTM), яка дає можливість отримувати структурну і спектроскопічну інформацію на молекулярному і субмолекулярному рівнях у прямому просторі [15].

Протягом останнього десятиліття за допомогою СТМ найбільш інтенсивно досліджували адсорбцію довголанцюжкових аліфатичних сполук на атомногладких підкладках - графіті і $\mathrm{Au}(111)$ [16, 17]. Підвищена увага до адсорбції аліфатичних сполук зумовлена їх важливістю в сучасних хімічних технологіях. До того ж молекули з аліфатичним ланцюгом $€$ зручними модельними об'єктами, дослідження яких дозволяє краще зрозуміти механізми адсорбції взагалі, особливо адсорбції великих молекул. Результати 
СТМ-спостережень нормальних алканів і їх похідних виявили, що структури пакування цього класу молекул, кінетика їх адсорбції і СТМ-контраст визначаються довжиною алкильного ланцюга, типом функціональної групи і типом підкладки. Незважаючи на інтенсивні дослідження у цьому напрямку, процеси самозбирання і властивості моношарів аліфатичних сполук ще недостатньо з'ясовані. Зокрема, це стосується важливих питань, пов'язаних з механізмами транспортування заряду крізь окремі молекули та фізикою формування СТМ-контрасту при спостереженні моношарів.

У цій роботі наведено результати СТМ-досліджень моношарових плівок гексадецилборної кислоти $\mathrm{CH}_{3}-$ $\left(\mathrm{CH}_{2}\right)_{15}-\mathrm{B}(\mathrm{OH})_{2}$, адсорбованих на атомно-гладкій поверхні графіту. Молекула гексадецилборної кислоти належить до класу алкилборних кислот і складається 3 насиченого алкильного ланцюга $-\mathrm{C}_{16} \mathrm{H}_{33}$ (довжина $\approx 1,7$ нм) і полярної групи $-\mathrm{B}(\mathrm{OH})_{2}$ (рис. 1$)$. Визначена за жорстким скелетом довжина молекули становить $\approx 1,9$ нм. Алкилборні кислоти широко використовуються в синтезі речовин-протекторів у хіміі вуглеводів, а також виступають в ролі прекурсорів для синтезу клатрохелатів [18]. За даними літератури, СТМ-дослідження адсорбції боромістких аліфатичних сполук до цього часу не проводились.

\section{2. Експеримент}

Підкладкою служила атомно-гладка поверхня високоорієнтованого піролітичного графіту, яку отримано шляхом сколювання монокристала графіту. Тверді гранули гексадецилборної кислоти розчиняли в нормальному тетрадекані $n$ - $\mathrm{C}_{14} \mathrm{H}_{30}$ (Aldrich) до концентрацій $\sim 0,1$ мг/мл. Краплю розчину наносили на підкладку в атмосферних умовах при кімнатній температурі. Структуру плівок досліджували за допомогою сканувального тунельного мікроскопа (NT MDT, Росія), адаптованого до вимірювань у рідинному середовищі. СТМ-вістря виготовляли із дроту $\mathrm{Pt} / \mathrm{Ir}$ (80:20), діаметром 0,25 мм шляхом механічного загострення. СТМ-вимірювання проводили в режимі сталого струму. Тунельний струм і електрична напруга на тунельному проміжку становили 10-500 пА і 1001000 мВ відповідно. У процесі СТМ-вимірювань вістря занурювали у краплину нанесеного на підкладку розчину. Температурний дрейф СТМ не перевищував 0,1 нм/хв. Відносна похибка визначення відстаней у латеральному напрямку була в межах 9\%. Калібрування п'єзоелементів СТМ здійснювали на основі СТМспостережень атомної структури графітової підклад-
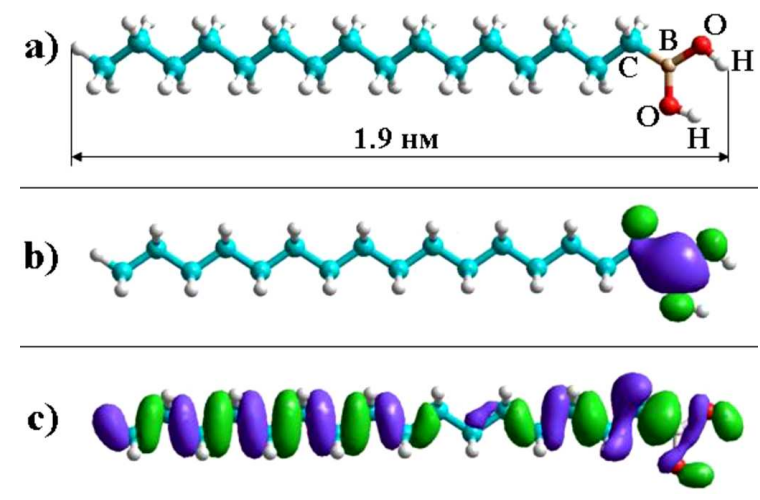

Рис. 1. Оптимізована методом функціоналу густини структура вільної нейтральної молекули гексадецилборної кислоти (a). Профілі перших граничних до рівня Фермі вакантних $(\mathrm{LUMO}+1)$ та заповнених (HOMO-1) молекулярних орбіталей для вільної нейтральної молекули гексадецилборної кислоти, розраховані за методом DFT/B3LYP/6-31G* (b), (c). Енергї $E=1,79 \mathrm{eB}(b)$ і $E=-8,01 \mathrm{eB}(c)$

ки. Отримані СТМ-зображення не піддавали процедурі фільтрації, за винятком корекції нахилу площини зразка, і були багаторазово відтворюваними з різними вістрями на різних ділянках підкладки.

Для інтерпретації СТМ-зображень було проведено квантово-хімічні розрахунки просторової та електронної структури вільної молекули гексадецилборної кислоти у нейтральному стані. Розрахунки виконували за методом функціонала густини (DFT) з гібридним функціоналом B3LYP, який складається 3 трипараметричного функціонала Бекке (В3) [19] та функціонала Лі, Янга і Парра (LYP) [20]. Таким чином, враховувалися як локальні, так і нелокальні кореляції. Усі обчислення проводили у стандартному для молекулярних розрахунків базисі 6-31G* за допомогою комерційного програмного пакета GAUSSIAN'03 з параметром збіжності $10^{-4} \mathrm{eB}$.

\section{3. Результати та обговорення}

Після нанесення розчину великомасштабні СТМзображення виявляли доменну структуру, в якій кожний домен складається із щільно упакованих паралельних ламелей (рис. 2). Кут між ламелями в сусідніх доменах становить $\approx 120^{\circ}$, тобто відповідає куту між еквівалентними кристалографічними напрямками монокристала графіту. Це дозволяє стверджувати, що адсорбована плівка і підкладка перебувають у епітаксіальному співвідношенні.

СТМ-зображення зменшеного масштабу (рис. 3) виявляє важливі особливості стосовно ширини ламе- 


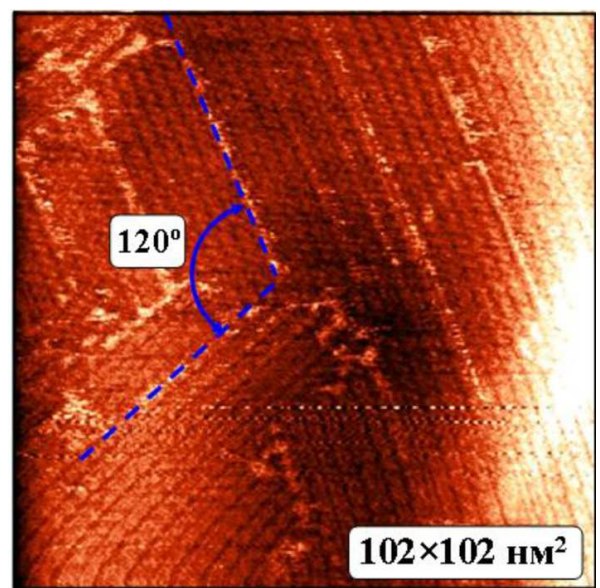

Рис. 2. СТМ-зображення моношару гексадецилборної кислоти на інтерфейсі $n$-тетрадекан/графіт. Площа сканування: $102 \times$ 102 нм$^{2}$. Тунельний струм $I_{t}=60$ пА, напруга на зазорі $U_{t}=$ $350 \mathrm{MB}$

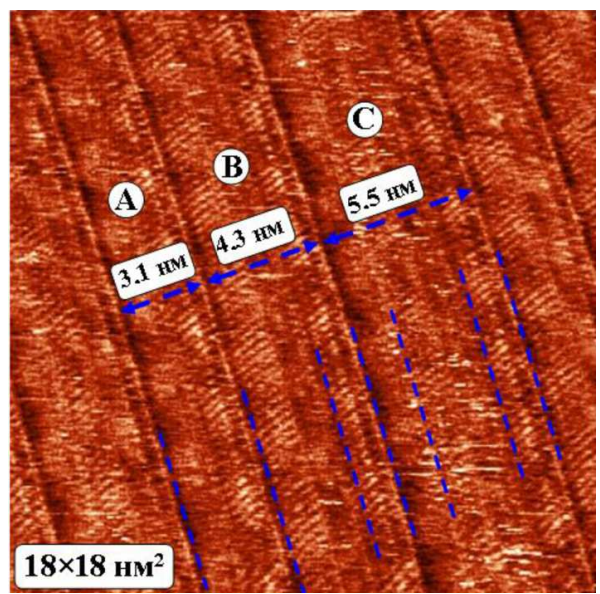

Рис. 3. Ламелеподібна структура моношару гексадецилборної кислоти на графіті. Три типи ламелей з різною шириною. Площа сканування: $18 \times 18$ нм$^{2}$. Тунельний струм $I_{t}=60$ пА, напруга на зазорі $U_{t}=300 \mathrm{mB}$

лей і контрасту границь між ними. Оцінка розмірів у межах похибки вимірювань показує, що ширина ламелей може відрізнятися на величину, кратну $\approx 1,2$ нм. На рис. 3 чітко видно три типи смужок: 3 шириною $\approx 3,1 \mathrm{Hм}, \approx 4,3$ нм і $\approx 5,5$ нм (умовно позначені $\mathbf{A}, \mathbf{B}, \mathbf{C})$. Можна також помітити, що ламель $\mathbf{C}$ із шириною $\approx 5,5$ нм складається 3 трьох вужчих субламелей, борозенки між якими мають слабкіший СТМ-контраст (позначені пунктирними лініями). Ламель В також складається з двох субламелей 3 різною шириною. Спроби досягти молекулярного розділення одночасно для трьох типів ламелей були

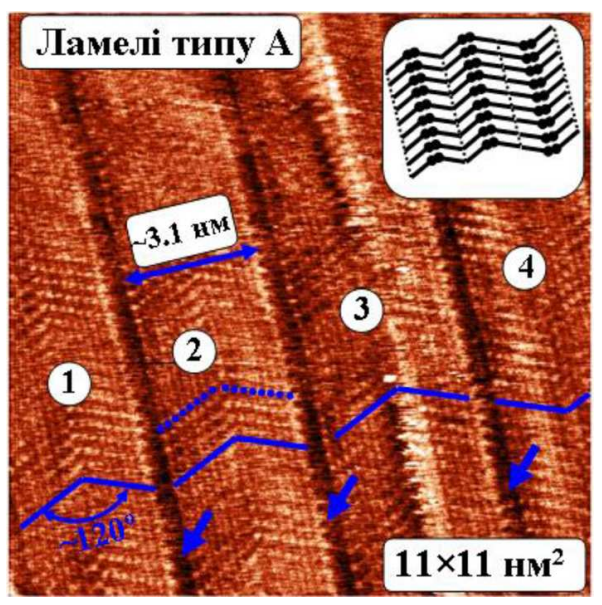

Рис. 4. Інтрамолекулярний розподіл моношару гексадецилборної кислоти на графіті. Ламелі утворені димерами молекул кислоти. Полярні групи $-\mathrm{B}(\mathrm{OH})_{2}$ розташовані в середині кожної ламелі. Плямками позначені положення $-\mathrm{CH}_{2}$-груп алкильного ланцюга. Площа сканування: $10 \times 10$ нм$^{2}$, тунельний струм $I_{t}=50$ пА, напруга на зазорі $U_{t}=350$ мВ. На вставці: схематична модель пакування

безуспішними. Дослідити молекулярну структуру пакування нам вдалось тільки для ламелей з шириною $\sim 3,1$ нм (тип А). СТМ-зображення з молекулярним розділенням (рис. 4) виявляе молекулярну структуру пакування ламелей А-типу. Як видно на рис. 4, кожна з чотирьох зображених ламелей складається із щільно впакованих " $\Lambda$ "-подібних об'єктів, кут між сторонами яких близький до $\sim 120^{\circ}$ (так звана "паркетна", або "ялинкова" структура). Подібні "ялинковi" структури пакування спостерігали в адсорбованих на графіті моношарах органічних спиртів [21]. Звертає на себе увагу те, що ламель 4 антипаралельна ламелям 1-3. Можна також помітити, що кожна сторона спостережених " $\Lambda$ "-об'єктів є рядком із восьми лінійно розташованих яскравих плямок (відзначені в ламелі 2). Принципово важливо, що відстань між сусідніми плямками збігається 3 періодом алкильного ланцюга ( $\approx 0,25$ нм), а їх кількість вдвічі менша за число $\mathrm{CH}_{2}$-груп в алкильному ланцюгу досліджуваної нами молекули гексадецилборної кислоти. Нагадаємо, що в той же час з літератури стосовно СТМдосліджень моношарових плівок нормальних алканів відомо, що на СТМ-зображеннях алкильних ланцюгів відображається тільки кожна друга $\mathrm{CH}_{2}$-група ланцюга [22]. Це пов'язано з нееквівалентністю сусідніх вуглецевих атомів підкладки графіту і, відповідно, з нееквівалентністю атомного оточення кожної другої $\mathrm{CH}_{2}$-групи адсорбованого на графіті алкильного ланцюга. Як наслідок, внески парних і не- 
парних $\mathrm{CH}_{2}$-груп у СТM-контраст суттєво відрізняються. У результаті на СТМ-зображеннях спостерігається тільки половина $\mathrm{CH}_{2}$-груп ланцюга. Так, на отриманому нами СТМ-зображенні моношару алкану $n$ - $\mathrm{C}_{46} \mathrm{H}_{94}$ (рис. 5) кожна молекула має вигляд 23 лінійно розташованих світлих плямок замість очікуваних 46. 3 урахуванням цього кожен рядок із 8 яскравих плямок на СТМ-зображенні (рис. 4) ми тлумачимо як алкильний хвіст молекули гексадецилборної кислоти, а самі “ $\Lambda$ ”-об'єкти - як пару асоційованих молекул (димер). Явище димеризації характерне для деяких довголанцюжкових молекул з певною полярною групою. Так, наприклад, в нашій попередній роботі ми спостерігали димеризацію в моношарах арахінової кислоти (полярна група -COОН). У роботі [23] було експериментально доведено, що парування молекул жирних кислот здійснюється завдяки взаємодії карбоксильних груп. Ми вважаємо, що у випадку гексадецилборної кислоти димеризація відбувається за рахунок взаємодії борних груп -B(OH $)_{2}$. Залишається відкритим питання щодо місцезнаходження борних груп. Якщо спиратися на результати проведених нами DFT-розрахунків граничних до рівня Фермі вакантних (LUMO+1) орбіталей (рис. 1,b), то можна очікувати підсилення СТМ-контрасту борних груп i, таким чином, провести їх ідентифікацію. Проте суттєвого підсилення СТМ-контрасту борних груп зареєструвати нам не вдалось, за винятком аномалій, спостережуваних у середній частині ламелі 3 (обговорюються нижче).

Для з'ясування місцезнаходження борних груп ми провели порівняльні експерименти по дослідженню чутливості СТМ-контрасту в моношарах алкану $n$ $\mathrm{C}_{46} \mathrm{H}_{94}$ (рис. 5) і гексадецилборної кислоти, які було отримано в однакових умовах. Було встановлено, що при зміні параметрів тунелювання (тунельний струм, напруга на зазорі) поведінка СТМ-контрасту темних борозенок між ламелями кислоти на рис. 4 і борозенок між ламелями алкану $n-\mathrm{C}_{46} \mathrm{H}_{94}$ (рис. 5) суттєво не відрізняється. Це дає підставу стверджувати, що темні борозенки на рис. 4 (відмічено стрілками) відповідають положенням кінцевих $\mathrm{CH}_{3}$-груп алкильних ланцюгів, як і борозенки між ламелями $n-\mathrm{C}_{46} \mathrm{H}_{94}$ на рис. 5. Звідси випливає, що молекули гексадецилборної кислоти утворюють структуру, в якій борні групи розташовані в середині кожної ламелі. Такий характер пакування підтверджується і нашими розрахунками оптимальної геометричної конформації молекули, яка відповідає мінімуму повної енергії (рис. 1,a). Це плоска конфігурація, в якій площина атомів бору та кисню збігається з площиною вуглеце-

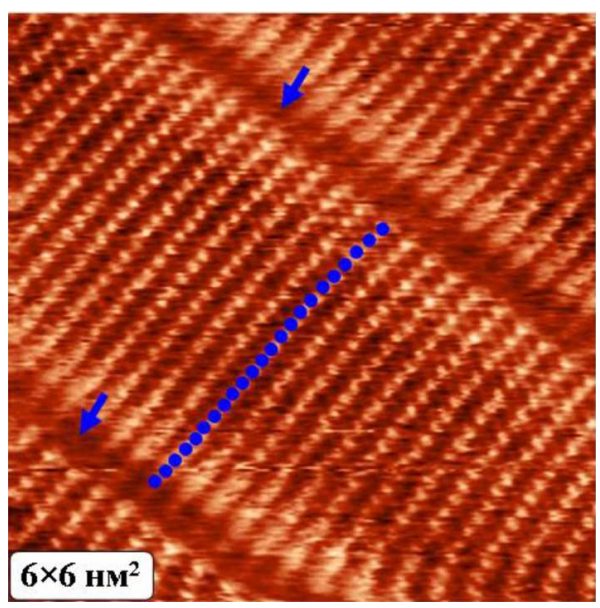

Рис. 5. Інтрамолекулярний розподіл моношару алкану $n$ $\mathrm{C}_{46} \mathrm{H}_{94}$ на графіті. Кількість видимих на СТМ-зображенні $\mathrm{CH}_{2}$-груп дорівнює 23 (позначені плямками) і рівно вдвічі менше, ніж містить молекула $\mathrm{C}_{46} \mathrm{H}_{94}$. Площа сканування: $6 \times 6$ нм$^{2}$, тунельний струм $I_{t}=50$ пА, напруга на зазорі $U_{t}=350$ $\mathrm{MB}$

вого хребта молекули. Саме така конфігурація добре узгоджується зі спостереженим пакуванням.

Повертаючись до СТМ-зображення на рис. 4, звернемо увагу на дві принципові особливості, які стосуються розмірів ламелей і аномалії СТМ-контрасту в середині ламелі 3. Більш ретельний аналіз відстаней показує, що ширина ламелі 3 приблизно на $10 \%$ перевищує ширину ламелей 1,2 і 4. Крім того, СТМконтраст у середній частині ламелі 3 аномально підвищений у порівнянні з ламелями 1,2 і 4. Оскільки ширина ламелі визначається розміром димерів, то відмінності в розмірах ламелей вказують на відмінності розмірів димерів, з яких ці ламелі сформовані. Спостережені розбіжності в розмірах можна пояснити особливостями асоціації молекул борної кислоти. Відомо, що алкилборні кислоти можуть утворювати димери, знаходячись у двох можливих станах - гідратованому і дегідратованому (рис. 6). Перехід у дегідратований стан супроводжується видаленням із кожної пари молекул одного атома кисню і двох атомів водню з утворенням вільної молекули води. Оскільки енергетичний бар'єр дегідратації не перевищує $0,1 \mathrm{eB}$, ймовірність такого процесу досить велика в умовах проведення наших експериментів. Очевидно, що розміри димерів у цих двох станах повинні відрізнятись. Отже, відмінності ширин ламелей на СТМ-зображенні (рис. 4), як і аномальне підсилення СТМ-контрасту в ламелі 3, ми пояснюємо різними станами молекул в парах - дегідратованим (в ламелях 1,2,4) і гідратованим (в ламелі 3). 


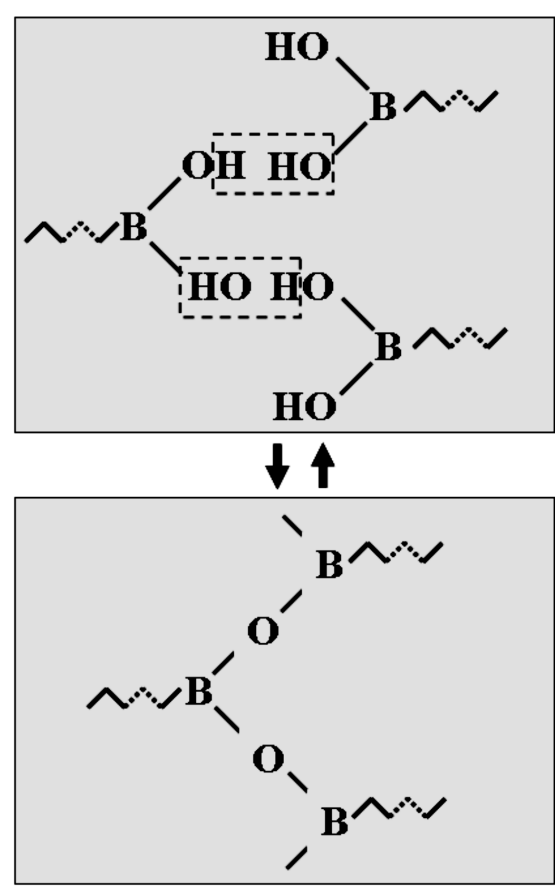

Рис. 6. Схематична модель асоціації молекул алкилборних кислот в гідратованому (зверху) і дегідратованому (знизу) стані. Пунктирними прямокутниками позначено атоми, які видаляються з молекул у процесі дегідратації

На завершення обговоримо природу вузеньких ламелей, наведених на рис. 3. Зауважимо, що їх ширина становить $\sim 1,2$ нм і добре узгоджується з величиною $l \cdot \sin 60^{\circ}$, де $l$ - довжина молекули $n$-тетрадекану $n$ $\mathrm{C}_{14} \mathrm{H}_{30}(\approx 1,6$ нм$) .3$ урахуванням цього ми інтерпретуємо їх як ламелі молекул розчинника, включені в моношар гексадецилборної кислоти. Фактично це означає утворення моношарового нанокомпозита, що складається з ламелей розчиненої речовини (кислоти) і розчинника (тетрадекану). Головні осі молекул $n$-тетрадекану у вузеньких ламелях утворюють кут $\sim 60^{\circ}$ з напрямком ламелей. Слід зауважити, що співадсорбція молекул $n$-тетрадекану з молекулами гексадецилборної кислоти спостерігається при температурі, значно вищій, ніж температура кристалізації моношару цієї речовини на графіті [22]. Це можна пояснити тим, що при формуванні моношарових ламелей гексадецилборної кислоти на поверхні можуть залишатися вільні ділянки, ширина яких уможливлює їх щільне заповнення молекулами $n$-тетрадекану при певній орієнтації цих молекул відносно поверхні графіту. Іншими словами, на поверхні створюються унікальні умови для просторового обмеження (конфайнменту) рухливості молекул $n$-тетрадекану - формується своєрідний молекулярний шаблон (template), який стимулюе впорядковану адсорбцію розчинника. Унікальність цих умов демонструється тим, що явище співадсорбції $n$-тетрадекану не спостерігається при нанесенні на поверхню графіту подібних аліфатичних молекул (нормальних спиртів, жирних кислот [24]). Це дозволяє розглядати бор-вмісні аліфатичні сполуки як перспективний клас речовин для створення двовимірних нанокомпозитів.

\section{4. Висновки}

Таким чином, у цій роботі показано, що високовпорядковані моношарові плівки гексадецилборної кислоти $\mathrm{CH}_{3}-\left(\mathrm{CH}_{2}\right)_{15}-\mathrm{B}(\mathrm{OH})_{2}$ можуть бути отримані на базисній площині високоорієнтованого піролітичного графіту при кімнатній температурі шляхом нанесення розчину кислоти в $n$-тетрадекані $n-\mathrm{C}_{14} \mathrm{H}_{30}$. За допомогою СТМ встановлено, що моношари сформовані димерами молекул гексадецилборної кислоти. Висунуто припущення, що асоціація молекул у парах здійснюється завдяки взаємодії між $\mathrm{B}(\mathrm{OH})_{2}$ групами. Експериментально виявлено, що молекули розчинника $n$ - $\mathrm{C}_{14} \mathrm{H}_{30}$, перебуваючи при температурі, значно вищій за температуру кристалізації моношару тетрадекану на графіті, можуть адсорбуватись на цій підкладці спільно з молекулами кислоти. Співадсорбція молекул $n$-тетрадекану і гексадецилборної кислоти може бути зумовлена сприятливими умовами конфайнменту для молекул $n$-тетрадекану.

Роботу виконано за фінансової підтримки Державної цільової науково-технічної програми "Нанотехнології та наноматеріали" (Договір № 1.1.1.1/11-Н-26), а також Українсько-російської двосторонньої програми "Розвиток співробітництва в галузі нанотехнологій між Україною та Російською Федерацією на 20092012 роки" (договір № M/91-2010).

1. A. Ulman, Chem. Rev. 96, 1533 (1996).

2. S. Chiang, Chem. Rev. 07, 1083 (1997).

3. J.F. Weaver, A.F. Carlsson, and R.J. Madix, Surf. Sci. Rep. 50, 107 (2003).

4. F. Schreiber, Progress in Surface Science 65, 151 (2000).

5. J.M. Tour, M. Kowaki, and J.M. Seminario, J. Am. Chem. Soc. 120, 8486 (1998).

6. S. Kubatkin, A. Danilov, M. Hjort, J. Cornil, J.-L. Bredas, N. Stuhr-Hansen, P. Hedegard, and N. Bjernholm, Nature 425, 698 (2003).

7. G.E. Poirier, Phys. Rev. Lett. 86, 83 (2001).

8. G. Hoffmann, L. Libioulle, and R. Berndt, Phys. Rev. B. 65, 212107 (2002). 
9. P. Byszewski, E. Kowalska, M. Poplawska, M. Luczak, and Z. Klusek, Journal of Magnetic Materials, 249, 486 (2002).

10. C.J. Brabec, N.S. Sariciftci, and J.C. Hummelen, Plastic Solar Cells 11, 15 (2001).

11. C.W. Tang and S.A. VanSlyke, Appl. Phys. Lett 51(12), 913 (1987).

12. Y. Sun, Y. Liu, and D. Zhu, J. Mater. Chem. 15, 53 (2005).

13. D. Sujeewa, M. Silva, X. Zeng, G. Ungar, and S.J. Spells, Macromolecules 35, 7730 (2002).

14. V.A. Shchukin and D. Bimberg, Reviews of Modern Physics 71(4), 1125 (1999).

15. J.S. Foster and J.E. Frommer, Nature 333, 542 (1998).

16. C.L. Claypool, F. Faglioni, W.A. Goddard, H.B. Gray, N.S. Lewis, and R.A. Marcus, J. Phys. Chem. B 101, 5978 (1997).

17. R. Yamada and K. Uosaki, Langmuir 14, 855 (1998).

18. J.B. Farmer, Adv. Ignor. Chem. Radiochem. 25, 187 (1982).

19. A. D. Becke, J. Chem. Phys. 98, 5648 (1993).

20. C. Lee, W. Yang, and R.G. Parr, Phys. Rev. B 37, 785 (1988).

21. B. Venkataraman, G. Flynn, J.L. Wilbur, J.P. Folkers, and G.M. Whitesides, J. Phys. Chem. 99, 8684 (1995).

22. G.G. McGonigal, R.H. Bernhardt, Y.H. Yeo, and D.J. Thomson, J. Vac. Sci. Technol. B 9(2), 1107 (1991).

23. J.P. Rabe, S. Buchholz, and L. Askadskaya, Synth. Met. 54, 339 (1993).

24. A.I. Senenko, D.V. Stryzheus., A.A. Marchenko, and A.G. Naumovets, Materialwissenschaft und Werkstofftechnik 42, 55 (2011).

Одержано 08.09.11

\section{САМООРГАНИЗАЦИЯ МОЛЕКУЛ \\ ГЕКСАДЕЦИЛБОРНОЙ КИСЛОТЫ \\ НА АТОМНО-ГЛАДКОЙ ПОВЕРХНОСТИ ГРАФИТА}

А.И. Сененко, А.А. Марченко, А.Г. Наумовеи,

Д.Т. Таращенко, Д.А. Глубоков, Я.З. Волошин,

А.А. Варзацкий, А.Л. Капитанчук

$\mathrm{P}$ е $з$ ю м е

Показано, что высокоупорядоченные монослойные пленки гексадецилборной кислоты $\mathrm{CH}_{3}-\left(\mathrm{CH}_{2}\right)_{15}-\mathrm{B}(\mathrm{OH})_{2}$ могут быть получены на базисной плоскости высоко-ориентированного пиролитического графита путем нанесения раствора кислоты в $n$-тетрадекане $n$ - $\mathrm{C}_{14} \mathrm{H}_{30}$ при комнатной температуре. С помощью сканирующего туннельного микроскопа (CTM) установлено, что монослои имеют ламелевидную структуру, в которой каждая ламель сформирована парами (димерами) молекул гексадецилборной кислоты. Ассоциация молекул в димерах осуществляется благодаря взаимодействию между $\mathrm{B}(\mathrm{OH})_{2}$ группами. Также обнаружено, что молекулы растворителя $n-\mathrm{C}_{14} \mathrm{H}_{30}$, находясь при температуре, существенно большей, чем температура поверхностной кристаллизации монослоя $n$ тетрадекана на графите, могут адсорбироваться совместно с молекулами кислоты. Соадсорбцию молекул растворителя можно объяснить спецификой взаимной геометрии поверхности подложки и димеров гексадецилборной кислоты.

\section{SELF-ORGANIZATION OF HEXADECYL BORON ACID MOLECULES ON ATOMICALLY FLAT SURFACE OF GRAPHITE}

A.I. Senenko ${ }^{1}$, A.A. Marchenko ${ }^{1}$, A.G. Naumovets ${ }^{1}$, D.T. Taraschenko ${ }^{1}$, D.A. Glubokov ${ }^{1,2}$, Ya.Z. Voloshin ${ }^{3}$, A.A. Varzatskiy ${ }^{4}$, A.L. Kapitanchuk ${ }^{5}$

${ }^{1}$ Institute of Physics, Nat. Acad. of Sci. of Ukraine (46, Nauky Prosp., Kyiv 03028, Ukraine)

${ }^{2}$ Lebedev Physical Institute, Russian Acad. of Sci.

(53, Leninskii Prosp., Moscow 11999, Russia),

${ }^{3}$ Nesmeyanov Institute of Organoelement Compounds, Russian Acad. of Sci.

(28, Vavilova Str., Moscow 119991, Russia),

${ }^{4}$ Vernadsky Institute of General and Inorganic Chemistry,

Nat. Acad. of Sci. of Ukraine

(32/34, Academician Palladin Prosp., Kyiv 03142, Ukraine),

${ }^{5}$ Bogolyubov Institute for Theoretical Physics,

Nat. Acad. of Sci. of Ukraine

(14-b, Metrolohichna Str., Kyiv 03680, Ukraine)

$\mathrm{S} \mathrm{u} \mathrm{m} \mathrm{m} \mathrm{a} \mathrm{r} \mathrm{y}$

It has been shown that highly ordered monolayer films of hexadecyl boron acid $\mathrm{CH}_{3}-\left(\mathrm{CH}_{2}\right)_{15}-\mathrm{B}(\mathrm{OH})_{2}$ can be obtained on the basal plane of highly oriented pyrolytic graphite by the deposition from a solution of the acid in $n$-tetradecane $n-\mathrm{C}_{14} \mathrm{H}_{30}$. Using the scanning tunneling microscopy, it has been found that the ordered monolayers have a lamella-like structure. In this structure, each lamella is composed of pairs (dimers) of molecules of the acid. The association of molecules in each pair is implemented through the interaction between $\mathrm{B}(\mathrm{OH})_{2}$-groups. It has been also found that molecules of solvent $n-\mathrm{C}_{14} \mathrm{H}_{30}$, being at a temperature sufficiently higher than the surface crystallization temperature can be coadsorbed with molecules of the acid. The coadsorption is explained by the geometric factor due to a specific size of the dimers of hexadecyl boron acid. 